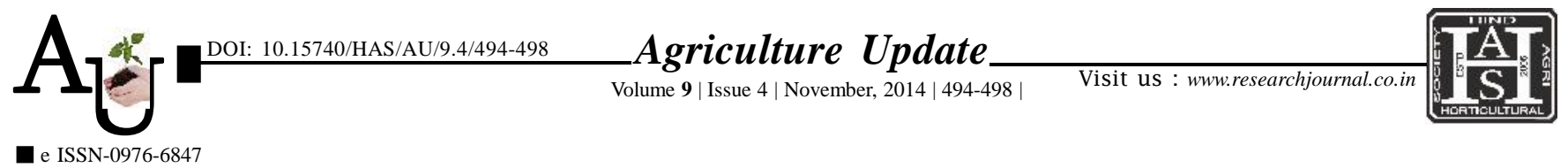

\title{
Research Article Enhancing yield and economics of field pea through front line demonstration
}

Article Chronicle:

Received :

16.07.2014;

Revised :

03.09.2014;

Accepted :

17.09.2014

KeY WORDS :

Economics,

Field pea,

Front line

demonstration,

Technology gap
SUMMARY : Field pea (Pisum sativum L.) is a good source of dietary protein to complement the cereal based diet, particularly for vegetarian masses in the country. It is a Rabi pulse crop which is highly productive and is grown for food, feed and vegetable. Present study was carried out in different villages (17) and blocks (03) of Sant Ravidas Nagar district. Fifty nine front line demonstrations on Malviya Matar-15, a promising cultivar of field pea developed from B.H.U., Varanasi were conducted during 2011 -12 and 2012-13 by KVK, Sant Ravidas Nagar. Appropriate interventions viz., improved variety of seed, balance application of fertilizers, weed control, proper seed rate, sowing methods, plant protection measures were adopted under front line demonstration on field pea. The results revealed that improved variety gave 32.9 and 36.89 per cent higher yield with net income Rs. 38402 and Rs. 46419 per hectare over local check variety 'Rachna' during respective years. However, benefit cost ratio was observed as 2.2 and 2.28 during 2011-12 and 2012-13, respectively. In the line of promotion of such improved technology, extensive field days were organized where the farmers of adjoining villages had seen the impact of improved technology at their own or nearby field. Presently, 48 per cent farmers are growing this variety successfully in adopted villages of KVK. Thus, the results of front line demonstration of field pea clearly indicated that by adoption of appropriate interventions, production and productivity of field pea could be enhanced substantially and providing suitable and sustainable option to farmers of eastern Uttar Pradesh.

How to cite this article : Chaudhary, R.P., Pandey, Rakesh, Chaturvedi, A.K. and Prasad, R. (2014). Enhancing yield and economics of field pea through Front line demonstration . Agric. Update, 9(4): 494-498.

Author for correspondence :

\section{R.P. CHAUDHARY}

Krishi Vigyan Kendra (IIVR) Bejwan, SANT RAVIDAS NAGAR (U.P.) INDIA

Email: rudalpd@ rediffmail.com

See end of the article for authors' affiliations 